\title{
Access to Finance, Financial Development and Firm Performance - Evidence from Pakistan
}

\section{Waqas Ahmad', Zaheer Abbas' ${ }^{2}$, Zulfiqar Ali Shah ${ }^{3}$}

${ }^{1} \mathrm{PhD}$ Scholar, FMS, International Islamic University Islamabad, Pakistan.

${ }^{2}$ Assistant Professor, FMS, International Islamic University Islamabad, Pakistan.

${ }^{3}$ Professor, FMS, International Islamic University Islamabad, Pakistan.

\section{A B S T R A C T}

The aim of the study is to investigate the impact of financial constraints on firm performance. The role of financial development in reducing the financial constraints is also investigated. Data from two waves of World Bank Enterprise Surveys from 2007 to 2013 was used to construct the required variables. A balanced sample of 427 firms were selected and fixed effect model was used for empirical estimations. The findings indicate the significance of access to finance in term of explaining firm performance. Improvement in access to finance led to subsequent improvement in firm performance as measured by labour productivity. The role of financial development in reducing credit constraints is not as expected. The concentration of lending to private sector in the hands of large corporations at the expense of small and medium enterprises could be reason for such result. Most of the work in this area is focused on large listed firms. The present study focused primarily on small and medium size enterprises in Pakistan. Multiple measure of financial constraints and firm performance were used for robustness. The investigation also covers the role of financial development and its microeconomic implications at the level of enterprise.

Key Words: Access to finance; Firm growth; Financial constraints; Financial Development; Pakistan

\section{INTRODUCTION}

Financial constraint is one of the important factors restricting the growth of firms specifically small and medium sized enterprises (SMEs) (Beck \& Demirgüç- Kunt, 2006). The work of (Ayyagari et al., 2010; Girma and Vencappa, 2015; Rajan and Zingales, 1998) documents the contribution of external finance for firm growth. The growth of firms without financing facility depend on size of internally generated fund thus limiting their growth. Chen and Guariglia, (2013) argued that the presence of asymmetric information led to credit rationing which adversely affect small enterprises. 
The outcome of financial development on long term economic growth and development is well documented in literature. (Levine, 1997 and 2005). These studies indicate the importance of a well development financial system, which can reduce credit constraints of firms and enable them to exploit growth opportunities. The lack of finance is more binding on firm growth than others factors such as corruption or infrastructure. Ayyagari, Demirgüç-Kunt, \&Maksimovic, (2008) presented the evidence that the young firms due to lack of the credit history and non-availability of collateral face more financial constraints. In case of some developing countries, studies have shown that there is no relationship between availability of external finance and firm growth (Beck et al 2015). The plausible explanation in this case could be weak regulatory framework for financial institution in many developing countries. Where large politically connected firms are more likely get credit despite low marginal return on capital at the expense of other firms. Some macro studies of financial development and economic growth also indicate the weakness of their relationship in many developing countries (Rousseau and Wachtel, 2011). The significance of bank credit is also tested by analyzing bank credit and export performance of banks during financial crises (Okafar et al 2020). There findings suggest the availability of credit led to increase in exporter's sales volume and increased in product lines during the crises.

In case of SMEs, due to high transaction cost associated with lending, opaqueness of firms, asymmetric information and lack of adequate collateral, the credit flow to SMEs don't fulfill their financing requirement. The estimated "financing gap" for SMEs in developing countries is around 2 trillion dollars (Stein et al 2010). Cao and Leung (2019) analyzed the credit constraints of Canadian small and medium enterprises and identified firm size, cash flow and current level of debt to asset ratio as predictor of credit constraints. They also concluded that productivity estimates can be upward biased by 4 percent if credit constraints variables are omitted. Credit constraints can be amplified due to lack of education and awareness of those operating small and medium enterprises as documented by Nguyan et al (2020) in case of Vietnam. They showed that there is self-rationing of credit by SMEs mainly due to lack of education.

The investing decisions and financial decisions are interlinked in economies 
where financial markets and institutions are not efficient. The corporate sector in Pakistan is currently receiving 70 percent of total bank lending as per recent report of Khalid et al (2017) of Stat Bank of Pakistan. This heavy concentration on the cost of other sectors of the economy like SME, agriculture and housing. This led to credit exposure of 30 percent to only 20 business groups in the Pakistan. The firms need external finance for investment to fuel their growth. The adoption of new technology for new product development and improvement of services also depend on availability of finance. These new investments can increase productivity of the firm. The lack of finance also hinders the development of new market and export (Minetti and Zhu 2011).

In emerging economies, the contribution of small and medium enterprise in export is at $40 \%$ and in case of high-income economies it is around $50 \%$. The number of SMEs in Pakistan stands at around 3 million, which is $90 \%$ of total establishments. This is based on rather dated economic census conducted in 2005, the number would be higher in view of the time elapsed since the economic census. SMEs output measured as percentage of GDP in Pakistan is 30\%. The export performance of SMEs measured; SME export as percentage of GDP are estimated as 25 percent, whereas in India this ratio is 40 percent. The credit disbursement to small and medium enterprise is at 7.6 percent of all private sector financing in December 2019, which has halved from its all-time peak of 15 percent in December 2007. If we compare bank lending in the region, Pakistan is at the bottom, In India it is 15 percent, Bangladesh 25 percent, and Sri Lanka 16 percent. The SME loan as share of GDP is also lowest in Pakistan at around only 1 percent. Where as in India it is 9 percent, Bangladesh 10 percent and Sri Lanka 8 percent (Aslam and Sattar 2017).

The purpose of this paper is twofold, first of all we would document access to finance and firm performance in Pakistan with focus on Small and medium enterprises. Secondly, we will investigate the role of financial development in reducing the financing constraints of firms. This is very imperative keep in view the role of SMEs in job creation, economic growth and forming a dynamic economic environment. The paper is organized as follow; after the introduction, section two outlies major theoretical and empirical literature, based on which hypothesis are formulated. Section three describe the 
methodology of the study. Section four presents the results and finally in section five lays down the conclusion and policy implications.

\section{LITERATURE REVIEW}

The theory of financial intermediation tries to explain the fundamental question of why financial intermediaries exist? If the invisible hand of Smith (2000) is sufficient to allocate the resources, then financial markets are sufficient to allocate the financial resources in an economy. This hypothesis is formalized in the traditional Arrow-Debreu (1954) model of resource allocation, which says that firms and household can interact through market for flow of funds and financial intermediary play no significant role in these allocations of funds. The model is put forward under certain assumptions like perfect market, symmetrical information, no taxes and transaction cost. In this case financial intermediaries cannot improve welfare. In the same context Modigliani and Miller (1958) hypothesized that financial structure does not matter under certain conditions.

The issue of financial constraints and its impact on firm performance is old but only recently the empirical evidence in this regard is documented. The primary issue here is the difficulty of measuring the notion of financial constraints. The literature on capital structure is built on Modigliani-Miller Theorem (1958) which informs us that source of finance both internal and external are perfect substitute thus financial structure and consequently financial policy is not relevent for the investment decisions of the firm. However, like many economic theories, there is strong assumption that capital market is perfect, which is far from reality, firm face difficulties in raising debt and equity. Stiglitz and Weiss (1981) present the case of asymmetric information in financial markets and its implications on financing decisions of firms. The asymmetric information in the capital market can result in classic lemon problem (Akerlof 1970). The difficulty of differentiating between lemon and peach can result into the problem of moral hazard and adverse selection.

\subsection{Financial Constraints and Firm Performance}

Financing is key to product and process innovations, expansion of operations and 
training of employees, all of these factors led to firm growth (OECD 2006b). Financing constraints has been identified as clear obstacle for firm sales growth in a study of developing countries (Beck, Demirgüç-Kunt, and Maksimovic 2005). The resulting implications for small firms are more acute, which is problematic as these small and medium enterprises contribute disproportionality in improving economic outcomes. Ayyagari, Demirgüç-Kunt, and Maksimovic (2008) studied the effect of different obstacles faced by firms in their sales growth. World Bank Enterprise Surveys (WBES) from eighty countries was used and concluded that finance is most significant hindrance for sales growth of the firm. Financing obstacle includes collateral, bureaucratic hurdles, exuberant internet rate among other things. They showed precisely that one standard deviation increases in obstacle resulted in 3.3 percent reduction in firm growth. The implications of financing constraints on firm with respect to their size is investigated by Beck et al (2005). They argue that firm growth is reduce by six percent for big firms and ten percent for small firms. The probability of highlighting financing constraints as key obstacle is 39,36, and 32 per cent for large, medium and small firms respectively (Beck 2007). Hashi et al (2001) documents in a country case study that financial constraints reduce asset and employment growth of Albanian firm. Naegels et al (2020) look at the issue of collateral, which is often highlighted by entrepreneurs, as one of the big issues in getting formal loan. They analyze both formal and informal networking with other entrepreneurs and conclude that while informal networking reduces credit constraints but formal networking increases the issue of credit constraints. Mehrotra \& Sergeyev (2020) studied the significance of availability of credit for job creations in the context of great recession of 2008. They showed that around 18 percent increase in unemployment in 2008 was due to credit constraints faced by firms. The export performance of firms is also affected by credit constraints. Chen et al (2020) investigate this issue in the Chines context and development of city commercial banks (CCBs) across China. They report that export performance of private Chinese firms has improved by establishment of CCBs.

The primary challenge in this area is the definition and measurement of financial constraints. The pioneering empirical work for the identification of financial constraints 
firm is done by Fazzari et al (1988) by looking at the impact of cash flow sensitivity on corporate investment. The result of the investigation based on 422 firms for the period (1970-1984) indicates that cash flow coefficient for low-dividend group is higher and statistically significance than high-dividend group. The first major challenge to sensitivity of cash-flow as measure of financial constraints is by Kaplan and Zingales (1997). They challenge the use of cash flow sensitivity as measure of financing constraints. The issue of asymmetric information and resulting problem of financial constraints is more severe for younger and smaller firms. (Petersen and Rajan 1995). Financial constraints are also partially responsible for the drastic difference in firm size distribution (Cooley and Quadrini 2001). The empirical result based on Italian manufacturing firm also vindicate the role of financial constraints in skewed distributin of firm size (Faggiolo and Luzzi 2006). The ability to raise finance when required is precondition for firm survival. Musso and Schiavo (2008) measures the financial constraints of French firms based on index and reported that financially constraints firm has high probability of failure and exit from the market. Firms operating in economies with develop financial system are less likely to face financial constraints (Love 2003). Falciola et al (2020) has gone beyond the national competitiveness and constructed a firm competitiveness by using WBES of more than 100 countries. They used multiple dimensions of competitiveness to construct the index. The availability of credit, along with other factors, is identified as important contributor to firm competitiveness. Machokoto, \& Areneke (2020) look at large sample of firms from nine African countries to investigate the impact of financial constraints on firm innovation. They firms operating in sample countries are innovating less due to financial constraints. The access to credit is also function of geography as there is clear big-city bias in access to finance. Lee and Lucas (2019) documents the big-city bias in availability of finance by analyzing data from 80,000 from 97 countries. Traditional financial institutions are less willing to finance SMEs. Venture capital are gaining prominence in many countries to fund innovative firms. $\mathrm{Wu}$ and $\mathrm{Xu}$ (2020) studied the role of venture in provision of loans to SMEs in China. They found firms backed by venture capital has low credit constraints, they get loan at lower cost and without collateral. 


\section{$\mathbf{H}_{1}$ : $\quad$ There is negative impact of financial constraints on firm performance.}

\subsection{Financial development, financial constraints and firm performance}

Levine $(1997,2005)$ presented some important functions of financial system that can affect economic growth through channels of technological innovation and capital accumulation. These functions are, allocating resources, mobilize saving, facilitate risk management, exert corporate control and ease of trading goods, services and contracts. The first two functions of allocating resources and mobilizing savings are more relevant to small and medium enterprises. The primary function of financial system is resource allocation. There are large costs associated with evaluating different investment opportunities before making investment, which an individual saver cannot afford. Investor will excess funds will be reluctant to invest; high information and monitoring cost will reduce the flow of capital to its most productive investment opportunity. Financial intermediaries not only help in efficient resource allocation but also increase the rate of technical innovation by identifying entrepreneurs with new innovative products and processes. Financial intermediaries and market can collect savings from disparate savers for lending. Financial intermediaries can increase saving mobilization in two ways. First; they reduce the transaction cost associated with collecting savings from numerous savers, due to economies of scale. Secondly financial intermediation reduces the moral hazard and adverse selection problems, which are main hindrance in saving mobilization. Financial intermediaries have to encourage savers of the safety of their investment. The survival rate of SMEs is generally not very high due to multitude of constraints they faced. Financial development in particular locality and branch concentration can increase the firm survival rate by providing timely financing as documented by Arcuric \& Levratto (2020) in the case of Italian SMEs. Omri (2020) investigate the interplay of governance, financial sector and entrepreneurship. He argues that improvement in financial sector has positive impact on formal entrepreneurship but negative on informal entrepreneurship. The weak effect on informal entrepreneurship can improved by better governance.

The micro evidence on the interaction between financial development, financial constraints and investment is investigated by Demirgüç-Kunt and Maksimovic (1998). 
They used micro data about listed manufacturing firms in 26 countries. They calculate the predicted growth of firm provided that only internal funds are used by the firm. This predicted growth is than compared with actual firm growth. The proportion of firms which has grown at higher rate than internal financed firm is in those countries where high bank development and efficient legal system. This result indicates the importance of financial development and its role in reducing financing constraints of the firms thus help them to grow at higher rate. These findings are confirmed at extended sample by Beck, Demirgüç-Kunt, and Levine (2001). The sensitivity of investment on internal cash flow is higher in countries with low level of financial development (Love 2003). The role of financial development in firm growth is far from settled. Zhu et al (2020) documents the implications of financial development in innovation led growth by taking data of 50 countries from 1990-2016. The results indicate that countries with high level of financial development shows small positive or insignificant impact on innovation. They also identify a threshold level; when private sector credit goes beyond 60 percent of GDP, the effect on firm innovation is insignificant. The presence of foreign banks has increased in many developing countries. Leon \& Zins (2020) analyzed the presence of international in African countries and reported that these international banks have reduced the credit constraints of firms operated in those countries.

Dabla-Norris et al (2020) analyzed financial inclusion and three dimensions of financial frictions. They argue that impact of financial inclusion program not only depends on particular constraints but also on the level of tightness of other constraints.

Financial inclusion; which broadly covers the availability and access to different financial services, can help the firms to growth at high rate by reducing their credit constraints (Lee et al 2019).

$\mathbf{H}_{2}$ : There is positive impact of financial development on firm performance.

$\mathbf{H}_{3}$ : There is positive impact of financial development on reducing financial constraints of firm.

\section{RESEARCH METHODOLOGY}

The role of financial development on macroeconomic outcomes like economic 
growth is extensively studied (Levine 1997 and Ang 2008). The micro evidence on the implication of financial on firm performance has also been documented in literature (Fazzari 1988 and Rajan 1995) but most of this research is on public listed firms because of availability of data. The non-listed small and medium enterprises, which contributes significantly in employment and output are not extensively studied especially in the context of developing countries like Pakistan. In the current study we will investigate the impact of financial constraints on firm performance and the role of financial development in mitigating this phenomenon.

The firm level data is based on World Bank's Enterprise Surveys (WBES). The Enterprise Surveys are conducted by the World Bank and its partners across all geographic regions. The surveys are administered to a representative sample of firms in the non-agricultural formal private economy1.

The Pakistan Enterprise Survey (ES), size stratification was defined following the standardized definition for the rollout: small (5 to 19 employees), medium (20 to 99 employees), and large (more than 99 employees). Two waves of World Bank Enterprise Surveys (WBES) for Pakistan conducted from 2007 - 2013 and released in 2015 are used in this current study. The final balanced panel sample of 427 firms is selected after excluding some observations due to non-availability of response to particular question in survey.

\subsection{Measurement of Variables}

The three areas of investigation in the current study are (a) Financial constraints (b) Firm Performance and (c) Financial Development. The quantification and measurement of financial constraints and firm performance are based on World Bank's Enterprise

Survey. The measure of financial development is from World Bank's financial development indicators.

\subsection{Dependent Variables}

The firms we are focusing are non-listed firms thus they don't have regulatory requirement of preparing financial statements. Mostly of the firms in our sample don't

\footnotetext{
${ }^{1}$ See (http://www.enterprisesurveys.org ) for more details about the survey.
} 
have at least audited financial statement.

The measures of firm performance, due to data constraints, are (a) employee growth and productivity (b) firm Innovation. The main data source that we are using here is World Bank's Enterprise Survey (WBES). It covers the required information to measures the selected firm performance indicators. Three measures of firm performance are constructed from WBES database.

Dependent variable in this research is performance of SMEs, which has been measured by using three proxies. These are as under

\section{Sale Growth}

Sale growth has been measured using following formula

$$
\text { S. } G_{\text {it }}=\frac{\text { Sales }_{\text {it }}-\text { Sales }_{\text {it }-1}}{\text { Sales }_{\text {it }-1}}
$$

Where S.G indicated sales growth in period t, measured by annual sales volume of firm $i$ in year $t$.

\section{Employee Growth}

Second measure of SME growth has been captured through using employee growth, which has been measured by

$$
E . G_{\text {it }}=\frac{\text { Employees }_{\mathrm{it}}-\text { Employees }_{\mathrm{it}-1}}{\text { Employees }_{\mathrm{it}-1}}
$$

Where E.Git indicates employee growth of firm $\mathrm{i}$ in year $\mathrm{t}$

\section{Labor Productivity}

In the literature, various measures of labor productivity have been used. However, most common method employed by researchers to gauge labor productivity is to measure it by calculating sales per employee. Same method has been used in this study

$$
L . P_{\text {it }}=\frac{\text { Sales }_{\text {it }}}{\text { Employees }_{\text {it }-1}}
$$

Where L.P is labor productivity of firm $\mathrm{i}$ in year $\mathrm{t}$

\subsection{Independent Variables}

Financial Constraints Rank.

The first objective measure of financial constraints is based on multiple questions in World Bank's Enterprise Survey (WBES). We are following Kuntchev et al (2013) in 
classifying the different level of credit constraints faced by firms. There are four groups of firms based on their credit constraints positions.

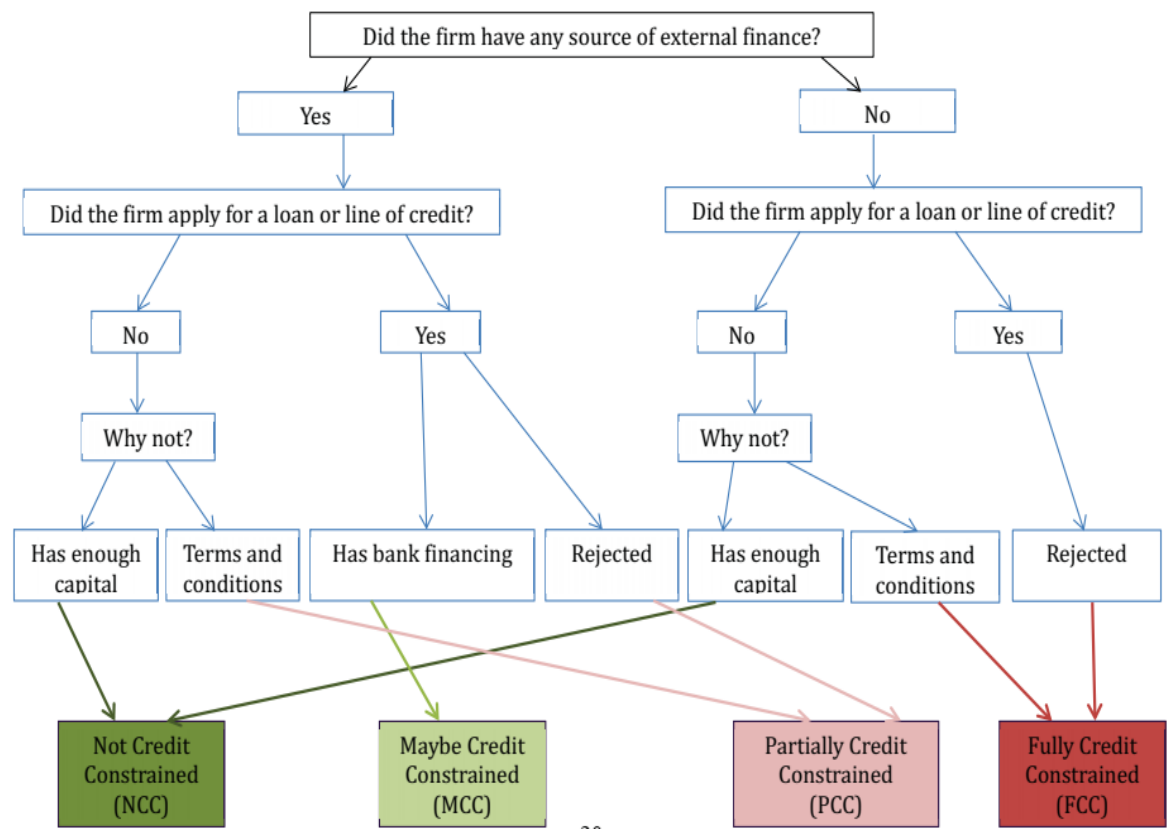

*Source: Kuntchev et al (2013)

This classification of firms is then used to rank the firm for the financial constraints they are facing. The Financial Constraints Ranking (FCR)is based on the following criteria.

- Fully credit constraints $(\mathrm{FCC})=1$

- Partially credit constraints $(\mathrm{PCC})=2$

- $\quad$ Maybe credit constraints $(\mathrm{MCC})=3$

- $\quad$ No credit constraints $(\mathrm{NCC})=4$

\section{Availability of overdraft}

Second measure of access to finance by SMEs is availability of overdraft facility extended by any bank. If a SME has this facility by bank then, generally SME does not have any problem to raise funds for positive NPV projects. Unavailability indicates that firm might not undertake positive NPV projects as well because of having no access to funds. This variable has been measured by dummy variable O.D, which takes value 1 , if firm has availed overdraft facility by bank and 0 otherwise. 


\section{Availability of bank account}

Another very strict measure of access to funds is availability of bank account. In countries like Pakistan, there is big chunk of undocumented industry where many entrepreneurs do not have even bank accounts, which is likely to affect performance of firms especially working in SME sector. This variable has also been measured by dummy variable, which take value of 1 if firm has bank account and 0 otherwise.

\section{Loan application}

Linkage of firm with financial sector has also been measured by dummy variable loan application. If firm has ever prepared loan application and submitted to any bank, this variable takes value of 1 otherwise 0 .

\section{Financial Sector Development}

Firm specific variables might not be enough to measure firm' access to funds. Supply side has also important role in firm access to finance. Therefore, interaction term of financial sector development and financial constraints been used to measure the contribution of financial sector development in the performance of financially constrained firm relative to non-constrained firm. Financial sector development has been measured using following formula

$$
F \cdot D_{\mathrm{t}}=\frac{P S C_{\mathrm{t}}}{G D P_{\mathrm{t}}}
$$

Where F.D indicated financial sector development in year $\mathrm{t}$

PSC indicated private sector development in year $\mathrm{t}$ and

GDP indicated gross domestic product measured in nominal values in year $\mathrm{t}$

\subsection{Empirical Models}

Two regression equations have been employed. First equation to measure the impact of regressors on performance of SMEs is

$$
F \cdot P_{\text {it }}=F \cdot C \cdot R_{\text {it }}+O \cdot D_{\text {it }}+B \cdot A_{\text {it }}+L \cdot A_{\text {it }}+\mu_{\text {it }}
$$

Where

F.P indicates firm performance, which has been measured through three different proxies namely Sales growth, employee growth and labor productivity

F.C.R indicates financial constrained measured on rank of 1 to 4 , where 1 
indicates no constraints while 4 indicates fully credit constrained.

O.D indicated overdraft facility availed from any bank measured through dummy variable having value of 1 , if SME has availed any facility of bank overdraft and 0 otherwise

- B.A indicates bank account taking value of 1 , if firm has bank account and 0 otherwise

- L.A is loan application taking value of 1 , if firm has submitted loan application and 0 otherwise.

- $\mu$ is residual of firm $i$ in year $t$

To measure the effect of interaction term of financial sector development and financial constraints, following regression equation has also been tested

$$
F \cdot P_{\text {it }}=F \cdot C \cdot R_{\text {it }}+O \cdot D_{\text {it }}+B \cdot A_{\text {it }}+L \cdot A_{\text {it }}+F \cdot C \cdot R_{\text {it }} * F \cdot S D_{\text {t }}+\mu_{\text {it }}
$$

Where F.SD indicates development of financial sector measured by dividing private sector credit with gross domestic product of year. Coefficient of this interaction term measures the contribution of financial development in financial performance of financially constrained firm.

As data of this research consists of 427 firms and two years, therefore, panel data techniques have been used. Generally, there are three models. First model is common effect model which ignores firm specific or year specific effect. Second model is fixed effect model which allows researchers to capture cross section fixed effect and year fixed effect for intercept as well as slopes. Third model is random effects model. Fixed effects likelihood test decides between common effects and fixed effects model while Hausman test decides between fixed effect model and random effect model.

\section{RESULTS AND DISCUSSION}

Before reporting results of regression equation, descriptive statistics of dependent and independent variables have been documented in table 1. 


\begin{tabular}{|l|c|c|c|l|l|l|l|l|}
\hline \multicolumn{1}{|l|}{ Table 1. Descriptive Statistics } \\
\hline & SG & EMPGROWTH & LABPROD & FCR & OD & BA & LA & FSD \\
\hline Mean & 0.098 & 0.098 & 5.814 & 2.280 & 0.256 & 0.805 & 0.099 & 0.215 \\
\hline Median & 0.079 & 0.000 & 5.796 & 1.000 & 0.000 & 1.000 & 0.000 & 0.270 \\
\hline Maximum & 2.282 & 2.485 & 9.012 & 4.000 & 1.000 & 1.000 & 1.000 & 0.270 \\
\hline Minimum & -2.745 & -2.303 & 3.125 & 1.000 & 0.000 & 0.000 & 0.000 & 0.160 \\
\hline Std. Dev. & 0.405 & 0.359 & 0.706 & 1.397 & 0.437 & 0.396 & 0.299 & 0.055 \\
\hline
\end{tabular}

Where SG is sales growth, empgrowth is growth rate of employees and labprod is labor productivity. FCR is financial constraints, OD is overdraft, BA is bank account, LA is loan application and FSD is financial sector development measured by dividing private sector credit by total gross domestic product. During sample years, SMEs have seen average growth of 9.8 percent per year with $228 \%$ maximum value and $-274 \%$ as minimum value. Standard deviation in this variable is 0.405 , which indicates that dispersion in sales growth is enough to be investigated. Mean value of employee growth is just similar to sales growth which is $9.8 \%$. Mean value of financial constraints is 2.28 which indicates that sample SMEs have just above average financial constraints, measured on scale of 4. Further, 25.6 percent of sample firms have overdraft facility extended by bank. Almost 80.5 percent of sample firms have bank account, however, firms which have applied for loan are on average 9.9\% which is not satisfactory and indicates that very small number of firms have access to bank financing. Private sector credit on average is $21.5 \%$ of total output of country with minimum value of $16 \%$ and maximum of $27 \%$.

\section{Results of Panel Data Analysis}

First of all, common effect model was run and then fixed effect model was applied. To judge, which is better, redundant fixed effect likelihood ratio was calculated. $\mathrm{P}$ value of fixed effect likelihood ratio is less that 0.05 thus rejecting the null hypothesis of no fixed effect. Then random effect model has been applied and to compare between fixed effect model and random effect model, Hausman test was applied. Null hypothesis was again rejected and thus it was concluded that fixed effect model is better than common effect model and random effect model. For the sake of parsimonious results, 
only fixed effect model's results are being reported. To check the robustness of results, performance of SMEs has been measured with three proxies, i.e. sales growth, employee growth and labor productivity. Results are reported in table 2

\begin{tabular}{|c|c|c|c|c|c|c|}
\hline \multicolumn{7}{|c|}{ Table 2. Results of Fixed Effect Model } \\
\hline & D.V=Sales Growth (1) & D.V=Employee Growth (2) & \multicolumn{2}{c|}{ D.V=labor productivity (3) } \\
\hline Variables & Coefficient & P value & Coefficient & P value & Coefficient & P value \\
\hline Intercept & 0.135 & 0.093 & 0.287 & 0.000 & 5.872 & 0.000 \\
\hline FCR & 0.013 & 0.351 & -0.010 & 0.401 & 0.049 & 0.016 \\
\hline OD & -0.009 & 0.853 & 0.046 & 0.276 & -0.001 & 0.985 \\
\hline BA & 0.148 & 0.007 & -0.061 & 0.178 & 0.253 & 0.001 \\
\hline LA & -0.016 & 0.822 & -0.077 & 0.199 & 0.193 & 0.056 \\
\hline FSD & -0.851 & 0.001 & -0.556 & 0.011 & -1.862 & 0.000 \\
\hline
\end{tabular}

Where FCR is financial constraints rank measured on scale of 1 to 4 , OD is dummy variable taking value of 1 , if SME has overdraft facility, BA is dummy variable taking value of 1, if SME has bank account and otherwise zero. LA is also a binary variable taking value of 1 , if SME has submitted any loan application and otherwise zero. FSD is financial sector development, which has been measured by dividing private sector credit by total GDP.

In first regression, explanatory variables have been regressed upon sales growth. In this output, none of independent variables is significantly affecting sales growth at $5 \%$ level of significance except financial sector development. Coefficient of bank account is significant at 10 percent level of significance. Its sign is positive. It indicates that SMEs have bank account experience almost 15\% higher sale growth than SMEs with no bank account. This supports our basic hypothesis that interaction of SMEs with banks increases the performance of SMEs. However, here we conclude that improvements in development of financial sector does not necessarily improve SME performance. It may be attributed to controlling share of corporate sector in private sector credit extended by banks.

To check the robustness of results, other measures of performance are employee growth and labor productivity. Financial sector development remains significant in all the three types of regression. Availability of bank account's contribution become more 
significant when regressed upon labor productivity. He we can say that labor productivity of firms having bank account is almost $25 \%$ higher than labor productivity on nonaccount holder. This is significant at $1 \%$ level of significance.

Coefficient of financial constraints has remained insignificant in first two regressions while it is significant and in expected direction in regression 3. Positive coefficient of FCR (0.049) indicates that firms with relatively fewer financial constraints experience higher performance, measured by labor productivity. This is significant at $5 \%$ level of significance.

\begin{tabular}{|c|c|c|c|c|c|c|}
\hline \multicolumn{7}{|c|}{ Table 3.Results of Fixed Effect Model-Moderation Equation } \\
\hline & D.V=Sales Growth & D.V=Employee Growth & \multicolumn{2}{c|}{ D.V=labor productivity } \\
\hline Variable & Coefficient & P value & Coefficient & P value & Coefficient & P value \\
\hline Intercept & -0.043 & 0.459 & 0.171 & 0.000 & 5.482 & 0.000 \\
\hline FCR & 0.102 & 0.000 & 0.042 & 0.057 & 0.214 & 0.000 \\
\hline OD & -0.017 & 0.736 & 0.042 & 0.320 & -0.014 & 0.844 \\
\hline BA & 0.143 & 0.009 & -0.065 & 0.152 & 0.240 & 0.002 \\
\hline LA & -0.020 & 0.780 & -0.079 & 0.187 & 0.193 & 0.056 \\
\hline FSD*FCR & -0.415 & 0.000 & -0.240 & 0.006 & -0.765 & 0.000 \\
\hline
\end{tabular}

Where

FSD*FCR is interaction term between financial sector development and financial constraints. All other variables are same as explained under table 2.

In table 3 , all the three regressions of table 2 have been run using interaction term. Our hypothesis is that improvement in development of financial sector reduces the impact of financial constraints on SMEs' performance. To capture this effect, an interaction term between financial constraints and financial sector development has been added in all the three regressions. Coefficient of interaction term is significant at 1 percent level of significance in first and third regression of table 3 while significant at 5\% level of significance in second regression. This negative coefficient indicates weakening impact of financial constraints on firm performance. Development of financial sectors weakens the contribution of financial constraints on firm performance by $41 \%, 24 \%$ and $76 \%$ in first, second and third regression respectively. Thus, from table 2 and table, we find that 
1. Interaction of SMEs with banks through bank account increases their performance measured by sales growth and labor productivity.

2. Financial constraints reduce the performance of SMEs measured through labor productivity.

3. SMEs do not have significant share in private sector credit as it does not appear to improve their performance.

4. However, development of financial sector moderates the relationship between financial constraints and SMEs performance.

\section{CONCLUSION}

The current study analyzed the impact of financial constraints on firm performance. The financial constraints are measured through three indicators; financial constrain rank, bank account and loan application. The non-listed small and medium size enterprise are focus of this analysis thus we used employee growth, sales growth and labour productivity as performance measures. The result reveals the importance of access to finance for better performance of firms. The financial development was expected to improve the performance of firms by reducing their financing constraints. The result indicates that in case of Pakistan this is not the case. We used private sector credit to GDP as measure of financial development, it appears that private sector credit in concentrated in large well-established firms and SMEs are not receiving required funding. Unless, funds are specifically allocated to SMEs sector, simple increasing lending to corporate sector would not yield the desired outcomes.

The improvement in macroeconomic environment is important as persistent fiscal deficit led to increase in government borrowing thus crowding out private sector. Zaheer et al (2017) analyzed the impact of government borrowing and conclude that a one percentage point increase in government borrowing led to decrease in private sector credit by eight percentage point. Public guarantee schemes are used by number of governments to increase the access to finance to SMEs. Movable assets represent significant portion of assets of SMEs but they cannot be used as collateral due to weak regulatory framework. Pakistan like other counties can initiate reforms in this regard to 
make it easy to get credit on the basis movable assets as collateral. Finally, in order to design and implement any policy to reduce the credit constraints, we need up- to -date information about SMEs and their financing requirement. This information can help researchers and policymakers to identify both demand and supply side impediments in easing the credit constraints of the firms.

\section{REFERENCES}

Akerlof, G. A. (1970). The Market for" Lemons": Quality Uncertainty and the Market Mechanism. The Quarterly Journal of Economics, 84(3), 488-500.

Ang James B. (2008). A survey of recent Development in the Literature of Finance and Growth. Journal of Economic Survey 22(3), 536-576

Arcuri, G., Levratto, N. Early stage SME bankruptcy: does the local banking market matter?. Small Bus Econ 54, 421-436 (2020). https://doi.org/10.1007/s11187018-0042-4

Arrow, K. J.; Debreu, G. (1954). "Existence of an equilibrium for a competitive economy". Econometrica. 22 (3), 265-290

Aslam, Ali Khizer and Sattar, Huma (2017) Nature and Characteristics of SME Financing and NPLs in Pakistan. Karandaaz Pakistan

Ayyagari, M., Demirgüç-Kunt, A., \& Maksimovic, V. (2008). How important are financing constraints? The role of finance in the business environment. The world bank economic review, 22(3), 483-516.

Ayyagari, M., Demirgüç-Kunt, A., \& Maksimovic, V. (2010). Formal versus informal finance: Evidence from China. The Review of Financial Studies, 23(8), 30483097.

Beck, T., Demirgüç-Kunt, A. and Maksimovic, V. (2005), Financial and Legal Constraints to Firm Growth: Does Firm Size Matter?, Journal of Finance 60, 137-177

Beck, T., Lu, L., \& Yang, R. (2015). Finance and growth for microenterprises: evidence from rural China. World Development, 67, 38-56.

Beck, T., \& Demirguc-Kunt, A. (2006). Small and medium-size enterprises: Access to finance as a growth constraint. Journal of Banking \& finance, 30(11), 2931-2943.

Beck, T. (2007, April). Financing constraints of SMEs in developing countries: Evidence, determinants and solutions. In KDI 36th Anniversary International Conference (pp. 26-27).

Boyd, J.H., and B.D. Smith. 1992. "Intermediation and the Equilibrium Allocation of Investment Capital: Implications for Economic Development." Journal of Monetary Economics 30: 409-32

Cao, S., \& Leung, D. (2019). Credit constraints and productivity of SMEs: Evidence from Canada. Economic Modelling. https://doi.org/10.1016/j.econmod.2019.09.018

Carpenter, R. E., Fazzari, S. M., \& Petersen, B. C. (1998). Financing constraints and inventory investment: $A$ comparative study with high-frequency panel data. Review of Economics and Statistics, 80(4), 513-519.

Chen, M., and Guariglia, A. (2013) Internal financial constraints and firm productivity in China: Do liquidity and export behavior make a difference? Journal of Comparative Economics 41(4), pp. 1123-1140

Chen, Z., Poncet, S., \& Xiong, R. (2020). Local financial development and constraints on domestic private-firm exports: Evidence from city commercial banks in China. 
Journal of Comparative Economics, 48(1), 56-75. https://doi.org/10.1016/j.jce.2019.09.005

Cooley, T. F., \& Quadrini, V. (2001). Financial markets and firm dynamics. American economic review, 91(5), 1286-1310.

Dabla-Norris, E., Ji, Y., Townsend, R. M., \& Unsal, D. F. (2020). Distinguishing constraints on financial inclusion and their impact on GDP, TFP, and the distribution of income. Journal of Monetary Economics. https://doi.org/10.1016/j.jmoneco.2020.01.003

Fagiolo, G., \& Luzzi, A. (2006). Do liquidity constraints matter in explaining firm size and growth? Some evidence from the Italian manufacturing industry. Industrial and Corporate Change, 15(1), 1-39.

Falciola, J., Jansen, M., \& Rollo, V. (2020). Defining firm competitiveness: A multidimensional framework. World Development, 129, 104857. Available in January https://doi.org/10.1016/j.worlddev.2019.104857

Fazzari, S., Hubbard, R. G., \& Petersen, B. (1988). Investment, financing decisions, and tax policy. The American Economic Review, 78(2), 200-205.

Girma, S., \& Vencappa, D. (2015). Financing sources and firm level productivity growth: evidence from Indian manufacturing. Journal of Productivity Analysis, 44(3), 283292.

Hashi, I., \& Krasniqi, B. A. (2011). Entrepreneurship and SME growth: evidence from advanced and laggard transition economies. International Journal of Entrepreneurial Behavior \& Research.

Kaplan, S. N., \& Zingales, L. (1997). Do investment-cash flow sensitivities provide useful measures of financing constraints?. The quarterly journal of economics, 112(1), 169-215.

Khalid, Asma., Talha Nadeem (2017) Bank credit to private sector: A critical review in the context of financial sector reform. Stat Bank of Pakistan Staff Note 3/17.

Kuntchev, V., Ramalho, R., Rodríguez-Meza, J., \& Yang, J. S. (2013). What have we learned from the enterprise surveys regarding access to credit by SMEs?. The World Bank.

Lee, C. C., Wang, C. W., \& Ho, S. J. (2020). Financial inclusion, financial innovation, and firms' sales growth. International Review of Economics \& Finance. https://doi.org/10.1016/j.iref.2019.11.021

Leon, F., \& Zins, A. (2020). Regional foreign banks and financial inclusion: Evidence from Africa. Economic Modelling, 84, 102-116.

Lee, N., \& Luca, D. (2019). The big-city bias in access to finance: evidence from firm perceptions in almost 100 countries. Journal of Economic Geography, 19(1), 199-224.

Levine, R. (1997). Financial development and economic growth: Views and agenda. Journal of Economic Literature, 35(2), 688-726.

Levine, R. (2005). Finance and growth: theory and evidence. Handbook of economic growth, 1, 865-934.

Levine, R., Demirgüç-Kunt, A., \& Beck, T. (2001). Law, politics, and finance. The World Bank.

Love, I. (2003). Financial development and financing constraints: International evidence from the structural investment model. The Review of Financial Studies, 16(3), 765-791.

Okafor, L. E., Bhattacharya, M., \& Apergis, N. (2020). Bank credit, public financial incentives, tax financial incentives and export performance during the global 
financial crisis. The World Economy, 43(1), 114-145.

Omri, A. (2020). Formal versus informal entrepreneurship in emerging economies: The roles of governance and the financial sector. Journal of Business Research, 108, 277-290.

Machokoto, M., \& Areneke, G. (2020). Does innovation and financial constraints affect the propensity to save in emerging markets? Research in International Business and Finance, 101185. https://doi.org/10.1016/j.ribaf.2020.101185

Mehrotra, N., \& Sergeyev, D. (2020). Financial shocks, firm credit and the Great Recession. Journal of Monetary Economics. https://doi.org/10.1016/j.jmoneco.2020.01.008

Minetti, R., \& Zhu, S. C. (2011). Credit constraints and firm export: Microeconomic evidence from Italy. Journal of International Economics, 83(2), 109-125.

Modigliani, F., \& Miller, M. H. (1958). The cost of capital, corporation finance and the theory of investment. The American economic review, 48(3), 261-297.

Naegels, V., D'Espallier, B., \& Mori, N. (2020). Perceived problems with collateral: The value of informal networking. International Review of Economics \& Finance, 65, 32-45

Nguyen, H.T., Nguyen, H.M., Troege, M. et al. Debt aversion, education, and credit selfrationing in SMEs. Small Bus Econ (2020). https://doi.org/10.1007/s11187-02000329-9

OECD (2006b). Financing SMEs and Entrepreneurs, OECD Policy Brief. Organization for Economic Co-operation and Development, Paris (November)

Musso, P., \& Schiavo, S. (2008). The impact of financial constraints on firm survival and growth. Journal of Evolutionary Economics, 18(2), 135-149.

Petersen, M. A., \& Rajan, R. G. (1995). The effect of credit market competition on lending relationships. The Quarterly Journal of Economics, 110(2), 407-443.

Rajan, G. R. and Zingales, L. (1998), Financial Dependence and Growth, American Economic Review,88, 559-586.

Rousseau, P. L., \& Wachtel, P. (2011). What is happening to the impact of financial deepening on economic growth? Economic inquiry, 49(1), 276-288.

Smith, Adam, 1723-1790. (2000). the wealth of nations / Adam Smith; introduction by Robert Reich; edited, with notes, marginal summary, and enlarged index by Edwin Cannan. New York: Modern Library,

Stein, P., Goland, T., \& Schiff, R. (2010). Two trillion and counting. International Finance Corporation and McKinsey \& Company

Stiglitz, J. E., \& Weiss, A. (1981). Credit rationing in markets with imperfect information. The American economic review, 71(3), 393-410.

Wu, L., \& Xu, L. (2020). The role of venture capital in SME loans in China. Research in International Business and Finance, 51, 101081.

Zaheer, Sajad,. Khaliq Fatima and Rafiq Muhamamd (2017) Does Government Borrowing Crowd out Private Sector Credit in Pakistan. SBP working paper series no 83.

Zhu, X., Asimakopoulos, S., \& Kim, J. (2020). Financial development and innovation-led growth: Is too much finance better? Journal of International Money and Finance, 100, 102083. 